\title{
Short communication \\ Dairy farm borehole water quality in the greater Mangaung region of the Free State Province, South Africa
}

\author{
L Esterhuizen ${ }^{1 *}$, A Fossey ${ }^{2}$ and JFR Lues ${ }^{1}$ \\ ${ }^{1}$ School of Environmental and Agricultural Sciences, Faculty of Health and Environmental Sciences, \\ 1 Park Road, Bloemfontein 9301, South Africa \\ ${ }^{2}$ Biotechnology, Faculty of Health and Environmental Sciences, 1 Park Road, Bloemfontein 9301, South Africa
}

\begin{abstract}
Most dairy farm effluent is discharged onto pastures and land by irrigation and poses a risk of enriching groundwater including borehole drinking water. Nitrate, coliforms and Escherichia coli (E. coli), in particular, may cause disease in humans and animals drinking contaminated water. The aim of this study was to obtain an understanding of the status of borehole drinking water quality, including physical, chemical and microbiological properties, on 75 dairy farms in the greater Mangaung region of the Free State, South Africa. Borehole drinking water samples were collected during autumn and spring of 2009 and the physical, chemical and microbiological parameters analysed and compared to the required standards prescribed by the South Africa National Standards (SANS) 241 of 2006. Most farms were compliant; however for combined nitrate and nitrite N, 37 of the farms exceeded the prescribed limit. Similarly, for total coliforms, 45, and for E. coli, 22 of the farms exceeded the acceptable limits. Nine of the farm boreholes were contaminated by $\mathrm{N}$ and $E$. coli. On two of the farms four of the chemical parameters exceeded the prescribed limits, including those for N; both farms were, however, compliant for E. coli. The results of this study suggest that further research on water and waste management on dairy farms in the Manguang region of the Free State should be conducted.
\end{abstract}

Keywords: Water quality; borehole drinking water; water standards; E. coli; coliforms; nitrate

\section{Introduction}

Dairy farming is a major contributor in the agricultural sector of South Africa, making a significant contribution to the economic development and sustainability of the country. Farm configurations are diverse, ranging from small enterprises with a few milk-producing cows to large industrialised farms comprising more than a thousand cows.

All dairy enterprises utilise water for all of the steps of the dairy industry, including cleaning, sanitisation, heating, cooling and floor washing. Dairy wastewater or dairy effluent is characterised by physical, chemical and microbiological parameters (Danalewich et al., 1998). In particular, it is known to have high biochemical and chemical oxygen demand, high levels of total dissolved solids including fats, oils and grease, and nutrients such as ammonia phosphates. As such, it must be treated (stabilised) appropriately before being discharged to the aquatic environment or re-used by disposal to land.

Faecally-derived pathogens, such as the Escherichia coli (E. coli) strain O157:H7, can impact water quality and human health, especially when the water is consumed without prior treatment (Oliver et al., 2009). It is well known that surface run-off from land during excessive periods of rainfall or discharge from dairy farms can pollute groundwater drinking water sources and have a significant adverse environmental impact on receiving surface waters (Atalay et al., 2008; Kay et al., 2008; Van der Schans et al., 2009). The harmful effect

\footnotetext{
* To whom all correspondence should be addressed.

푤 +27 51 507-3850; fax: +27 51 507-3435;

e-mail: lesterhu@cut.ac.za

Received 31 March 2011; accepted in revised form 19 September 2012.
}

of agricultural activities on groundwater and surface water (Monaghan et al., 2009) is becoming more of a concern worldwide (Santhi et al., 2006). For example, elevated concentrations of ammoniacal nitrogen and phosphate found in receiving watercourses from farm effluent are harmful to both farm animals and the indigenous wildlife, if used as drinking water sources, and to the aquatic micro- and macro-fuana within such water bodies. Equally of concern is the potential for groundwater sources to become contaminated, as such water is consumed as drinking water often without any further treatment. Therefore, it is important that farm effluent is adequately treated and stabilised before being allowed to discharge to water or disposed of to land (Willcock et al., 1999).

South Africa is a water-scarce country and the central region, which includes the Free State Province, is an arid area. In the Mangaung area of the Free State, surface water is limited to a few seasonal streams and the low-flowing Modder River. The majority of dairy farms in this area are not close to any surface water source and utilise groundwater (borehole water) for all dairy activities and for drinking water. Groundwater is the main source of potable water for the majority of rural and farming communities in South Africa. These communities often have no other available water source (Van Tonder, 2009). A study on the handling practices of dairy effluent in South Africa by Strydom et al. (1993) showed that most farm effluent was discharged onto pastures and land by irrigation. With the increasing growth of the dairy industry together with the risk posed by dairy effluent, there is no doubt that measures to protect groundwater sources should be instituted. However, information about the impact of dairy effluent on groundwater is limited (Harter et al., 2002), particularly so in South Africa. The aim of this study was to obtain an understanding of the 
status of borehole drinking water quality, including physical, chemical and microbiological properties, on 75 dairy farms in the Mangaung region of the Free State Province, South Africa.

\section{Materials and methods}

One borehole water sample was collected from each of 75 farms in the greater Manguang region during autumn and spring of 2009. This central region of the Free State Province covers a surface area of $6263 \mathrm{~km}^{2}$ and hosts approximately 850000 people. Samples were collected using the prescribed sampling methods of the Department of Water Affairs (DWAF, 2006) and standard sampling and analytical procedures as prescribed by South African National Standards 241 (SANS, 2006). The physical, chemical and microbiological parameters were analysed and examined according to the standard methods laid down in South Africa National Standards (SANS) 241 of 2006. Fourteen parameters were analysed: $\mathrm{pH}$, electrical conductivity, total hardness $\left(\mathrm{CaCO}_{3}\right)$, chloride $(\mathrm{Cl})$, sulphate $\left(\mathrm{SO}_{4}\right)$, phosphate $\left(\mathrm{PO}_{4}\right)$, combined nitrate and nitrite $(\mathrm{N})$, fluoride $(\mathrm{F})$, calcium $(\mathrm{Ca})$, magnesium $(\mathrm{Mg})$, sodium $(\mathrm{Na})$, potassium (K), E. coli and total coliforms.

Summary statistics were calculated for the different parameters and correlations established between $\mathrm{N}$ and $E$. coli concentrations, $\mathrm{N}$ and coliform bacteria, as well as between coliform and E. coli concentrations.

A water quality index (WQI) was calculated for each borehole to summarise the borehole water quality data. The WQI formula was devised by the Canadian Council of Ministers of the Environment (Saffran et al., 2001). The WQIs were used to rank the boreholes according to 'excellent' (values 95-100), 'good' (values 80-94), 'fair' (values 65-79), 'marginal' (values 45-64) and 'poor' (values 0-44).

\section{Results}

Generally, the physical and chemical properties of the borehole water of the 75 farms were within the prescribed SANS 241 (2006) limits, except for $\mathrm{N}$ (Table 1). The $10 \mathrm{mg} / \ell$ limit for $\mathrm{N}$ was exceeded by $49.3 \%$ of the farm boreholes, also demonstrated by the mean value as well as the median value being greater that the SANS 241 (2006) limit. When the N concentrations were compared to WHO (2008) standards, only 2 farms exceeded the limit of $50 \mathrm{mg} / \ell$ with values of 65.05 and 68.00 $\mathrm{mg} / \ell$.

Boreholes on 22 farms (29.3\%) were found to be contaminated with $E$. coli, while more than half $(60 \%)$ of the boreholes exceeded the prescribed SANS 241 (2006) and WHO (2008) limits for total coliform bacteria $(<10 \mathrm{cfu} / 100 \mathrm{~m} \ell)$ and $E$. coli $(0 \mathrm{cfu} / 100 \mathrm{~m} \ell)$ collectively (Table 2$)$.

Nine of the farm boreholes were found to contain water with elevated levels of $\mathrm{N}$ and $E$. coli beyond the recommended SANS 241 (2006) standards. All of the bacteriological parameters and 4 of the chemical parameters, including $\mathrm{N}$, were exceeded by 1 of the 75 farms. Two other farms presented similarly poor results for chemical parameters; however E. coli levels were compliant on these farms. One of these two farms displayed exceeding levels of $\mathrm{Ca}, \mathrm{Mg}, \mathrm{Cl}$ and $\mathrm{N}$; while the other farm exceeded the levels of $\mathrm{Mg}, \mathrm{Na}, \mathrm{F}, \mathrm{Cl}$, and $\mathrm{N}$.

There was a moderate positive correlation between $\mathrm{N}$ and E. coli concentrations $\left(r=0.33, r^{2}=0.11, p=0.004\right), \mathrm{N}$ and coliform bacteria $\left(r=0.5, r^{2}=0.25, p=<0.001\right)$, as well as between coliform and E. coli $\left(r=0.59, r^{2}=0.35, p<0.001\right)$ (Fig. 1).

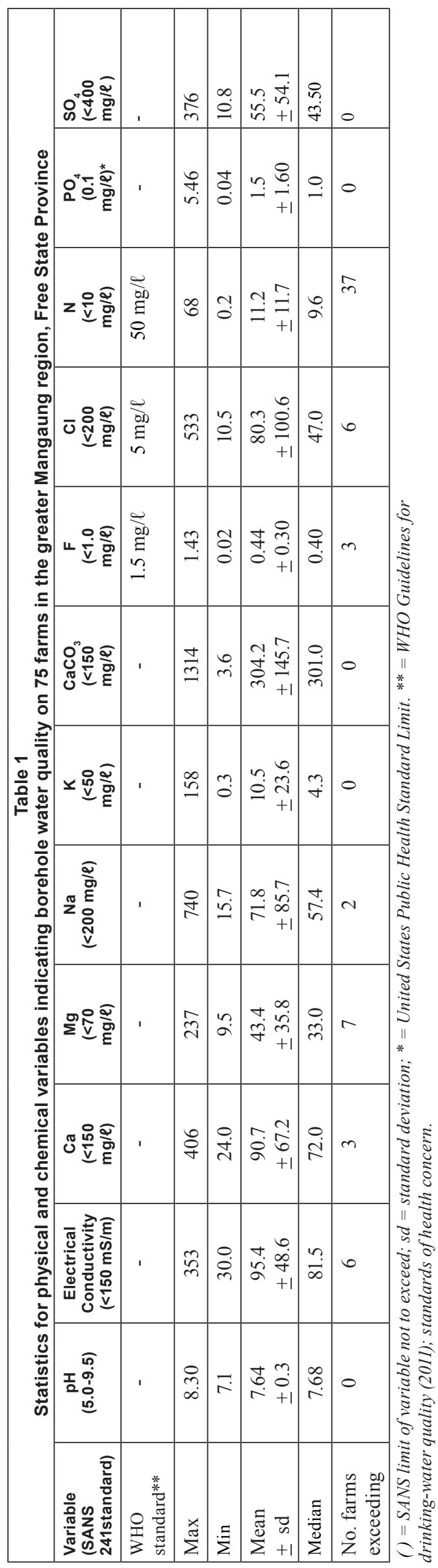

http://dx.doi.org/10.4314/wsa.v38i5.20 Available on website http://www.wrc.org.za ISSN 0378-4738 (Print) $=$ Water SA Vol. 38 No. 5 October 2012 ISSN 1816-7950 (On-line) = Water SA Vol. 38 No. 5 October 2012 


\begin{tabular}{|l|c|c|c|}
\hline \multicolumn{4}{|c|}{ Table 2 } \\
\hline Bariable & $\begin{array}{c}\text { Number } \\
\text { of farms }\end{array}$ & $\begin{array}{c}\text { Total coliforms* } \\
(\mathbf{1 0 )}\end{array}$ & $\begin{array}{c}\text { Total } \\
\text { E. coli (0) }\end{array}$ \\
\hline Max & 75 & $>2419^{* *}$ & 1414 \\
\hline Min & & 0 & 0 \\
\hline Mean \pm sd & & $171.11 \pm 704.5$ & $62.83 \pm 323.9$ \\
\hline $\begin{array}{l}\text { No. of non- } \\
\text { compliant farms }\end{array}$ & & 45 & 22 \\
\hline
\end{tabular}

*Farms non-compliant because E. coli burden excluded from Total Coliforms;

()$=$ number of organisms to not be exceeded;

** = values exceeding 2419 were recorded as $>2$ 419;

$s d=$ standard deviation .

WQIs of the boreholes ranged from 91.9 to 100 , of which $68 \%$ of the boreholes were ranked as 'excellent' and $32 \%$ as 'good'.

\section{Discussion and conclusions}

Dairy farm effluent, which refers to the dung and urine deposited during milking, is subsequently diluted during washing down of the milking shed floor polluting groundwater, drinking water sources and streams (Hooda et al., 2000). Animal wastes are a major source of nutrient enrichment of streams from run-off from dairies (Willcock et al., 1999) and therefore groundwater quality has become a major concern, particularly because of salt and nitrate leaching, often demonstrated by intense agricultural activities (Mohammad and Kaluarachchi, 2004). Therefore, manure handling and disposal practices in dairy enterprises are currently undergoing critical revision to reduce their impact on groundwater quality (Goss and Richards, 2008).

As dairy farming is a contributor of anthropogenic nitrogen worldwide, it was not surprising that some of these dairy farms displayed high $\mathrm{N}$ levels in the borehole drinking water. In this study the enrichment of groundwater maybe attributed mostly to animal waste and run-off from the dairies. On some of the farms the $\mathrm{N}$ levels were exceptionally high, up to 7 times greater than the specified health limit. These high toxic levels of nitrate are of a concern for the expression of methaemoglobinemia ('blue baby syndrome') in infants less than 6 months of age (Ward et al., 2005). Acute toxicity has been documented at concentrations $>50 \mathrm{mg} / \ell$ (Spalding and Exner, 1993), but methaemoglobinemia has never been recorded at levels lower than $6 \mathrm{mg} / \ell$ (Kempster et al., 1997).

Although the WQIs for all of the farms were greater than 91, categorising the drinking water from these farms as either being 'excellent' or 'good', it should be noted that nearly $30 \%$ of the farm boreholes displayed non-compliance with the national standard (SANS) 241 of 2006 for E. coli. E. coli numbers for 6 of the boreholes were between 10 and 100 organisms per $100 \mathrm{~m} \ell$, which can be considered as being high risk, whereas 5 of the boreholes recorded levels above 100 organisms per $100 \mathrm{~m} \ell$, posing a severely high risk to the users. Because these boreholes are the sole drinking water sources on these farms, humans and animals are therefore at risk of contracting gastrointestinal diseases (Pell, 1997).

The contaminated water could further contribute to the decrease of the quality of dairy products and other farming produce (Jones, 1999, Schneider et al. 2010). It can therefore be concluded that this baseline study strongly suggests that further

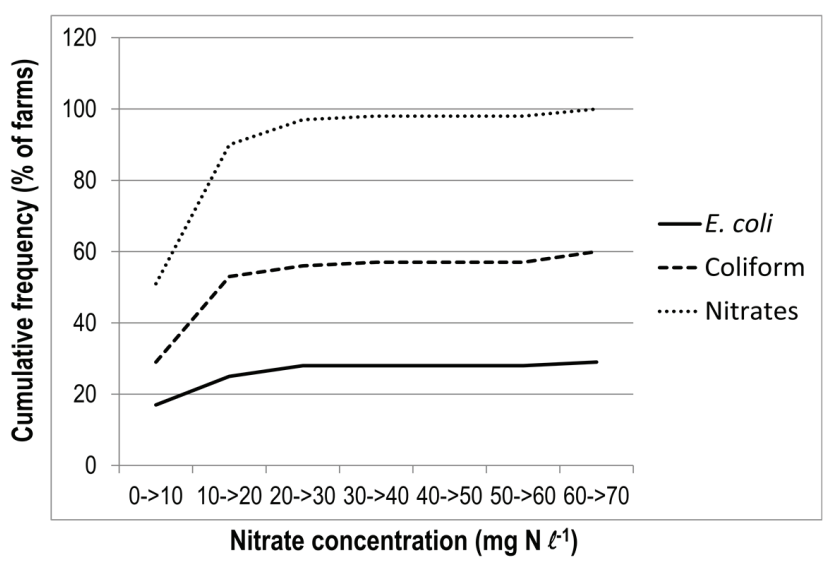

Figure 1

Cumulative frequencies for the 2 major groups of bacterial contamination (E. coli and coliform) and nitrates

studies should be undertaken to provide insights into water and waste water management strategies on dairy farms in the Manguang region.

\section{Acknowledgements}

The authors wish to thank Mr. Barns (Manager, Environmental Health) from the Manguang Local Municipality for making the water quality data available for the study.

\section{References}

ATALAY A, PAO S, JAMES M, WHITEHEAD B and ALLEN A (2008) Drinking water assessment at underserved farms in Virginia's coastal plain. J. Environ. Monit. Restor. 4 53-64. DANALEWICH JR, PAPAGIANNIS TG, BELYEA MRL, TUMBLESON ME and RASKIN L (1998) Characterization of dairy waste streams, current treatment practices, and potential for biological nutrient removal. Water Res. 32 (12) 3555-3568.

DWAF (DEPARTMENT OF WATER AFFAIRS AND FORESTRY, SOUTH AFRICA) (2006). Minimum Requirements for Sampling Drinking Water Systems: A User-Friendly Summary Guide. Version 1. Department of Water Affairs and Forestry, Pretoria.

GOSS M and RICHARDS C (2008) Development of a risk-based index for source water protection planning, which supports the reduction of pathogens from agricultural activity entering water resources. J. Environ. Manage. 87 623-632.

HARTER T, DAVIS H, MATHEWS MC and MEYER RD (2002) Shallow groundwater quality on dairy farms with irrigated forage crops. J. Contam. Hydrol. 55 287-315.

HOODA PS, EDWARDS UAC, ANDERSON HA and MILLER A (2000) A review of water quality concerns in livestock farming areas. Sci. Total Environ. 250 143-167.

JONES DL (1999) Potential health risks associated with the persistence of Escherichia coli 0157 in agricultural environments. Soil Use Manage. 15 (2) 78-83.

KAY D, CROWTHER J, FEWTRELL L, FRANCIS AC, HOPKINS M, KAY C, MCDONALD AT, STAPLETON CM, WATKINS J, WILKINSON J and WYER MD (2008) Quantification and control of microbial pollution from agriculture: a new policy challenge? Environ. Sci. Polic. II 171-184.

KEMPSTER PL, VAN VLIET HR and KUHN A (1997) The need for guidelines to bridge the gap between ideal drinking-water quality and that quality which is practically available and acceptable. Water SA 23 (2) 163-167.

MOHAMMAD NA and KALUARACHCHI JJ (2004) Assessment and management of long-term nitrate pollution of ground water in agriculture-dominated watersheds. J. Hydrol. 295 225-245. 
MONAGHAN RM, CAREY PL, WILCOCK RJ, DREWRY JJ, HOULBROOKE DJ, QUINN JM and THORROLD BS (2009) Linkages between land management activities and stream water quality in a border dyke-irrigated pastoral catchment. Agric. Ecosyst. Environ. 129 201-211.

OLIVER DM, FISH RD, HODGSON CJ, HEATHWAITE AL, CHADWICK DR and WINTER M (2009) A cross-disciplinary toolkit to assess the risk of faecal indicator loss from grassland farm systems to surface waters. Agric. Ecosyst. Environ. 129 401-412.

PELL AN (1997) Manure and microbes: Public and animal health problem? J. Dairy Sci. 80 267-2681.

SAFFRAN K, CASH K and HALLARD K (2001) Canadian water quality guidelines for the protection of aquatic life. Water Quality Index 1.0 User's Manual. Canadian Environment Quality Guidelines. Canadian Council of Ministers of the Environment, Winnipeg.

SANTHI C, SRINIVASAN R, ARNOLD JG and WILLIAMS JR (2006) A modelling approach to evaluate the impacts of water quality management plans implemented in a watershed in Texas. Environ. Model. Softw. 21 1141-1157.

SANS 241 (2006) South African National Standard, Drinking Water Standard. Standards South Africa (a division of SABS)

SCHNEIDER KR, GOODRICH-SCHNEIDER R and ARCHER DL (2010) Food Safety on the farm: Good agricultural practices Water (revised). FSHN 06-02. University of Florida, Gainesville.
SPALDING RF and EXNER ME (1993) Occurrence of nitrate in groundwater - A review. J. Environ. Qual. 22 392-402.

STRYDOM JP, MOSTERT JF and BRITZ TJ (1993) Effluent production and disposal in the South African dairy industry: A postal survey. Water SA 19 (3) 253-258.

VAN DER SCHANS ML, HARTER T, LEIJNSE A, MATHEWS MC and MEYER RD (2009) Characterizing sources of nitrate leaching from an irrigated dairy farm in Merced County, California. J. Contam. Hydrol. 110 9-21.

VAN TONDER G (2009) Groundwater management under the new Water Act in South Africa. Hydrogeol. J. 7 421-422

WARD MH, DEKOK TM, LEVALLOIS P, BRENDER J, GULIS G, NOLAN BT and VAN DERSLICE J (2005) Workgroup report: Drinking-water nitrate and health - recent findings and research needs. Environ. Health Perspect. 113 (11) 1607-1614.

WHO (WORLD HEALTH ORGANIZATION) (2008) Guidelines for Drinking-water Quality $\left(3^{\text {rd }}\right.$ edn. incorporating the first and second addenda). Volume 1, Recommendations. World Health Organisation, Geneva.

WILCOCK RJ, NAGELS JW, RODDA HJE, O'CONNER MB, THORROLD BS and BARNETT JW (1999). Water quality of a lowland stream in a New Zealand dairy farming catchment. NZ J. Mar. Freshwater Res. 33 683-696. 